\title{
A Novel Inorganic Low Melting Electrolyte for Secondary-Aluminum-Nickel Sulfide Batteries
}

\author{
Hjuler, H.A.; Winbrush, S. von; Berg, Rolf W.; Bjerrum, Niels
}

Published in:

Journal of The Electrochemical Society

Link to article, DOI:

$10.1149 / 1.2096875$

Publication date:

1989

Document Version

Publisher's PDF, also known as Version of record

Link back to DTU Orbit

Citation (APA):

Hjuler, H. A., Winbrush, S. V., Berg, R. W., \& Bjerrum, N. (1989). A Novel Inorganic Low Melting Electrolyte for Secondary-Aluminum-Nickel Sulfide Batteries. Journal of The Electrochemical Society, 136(4), 901-906. https://doi.org/10.1149/1.2096875

\section{General rights}

Copyright and moral rights for the publications made accessible in the public portal are retained by the authors and/or other copyright owners and it is a condition of accessing publications that users recognise and abide by the legal requirements associated with these rights.

- Users may download and print one copy of any publication from the public portal for the purpose of private study or research.

- You may not further distribute the material or use it for any profit-making activity or commercial gain

- You may freely distribute the URL identifying the publication in the public portal 


\title{
ELECTROCHEMICAL SCIENCE \\ AND TECHNOLOGY

\section{A Novel Inorganic Low Melting Electrolyte for Secondary Aluminum-Nickel Sulfide Batteries}

H. A. Hjuler*

Molten Salts Group, Chemistry Department A, The Technical University of Denmark, 2800 Lyngby, Denmark

\author{
S. von Winbush*
}

State University of New York at Old Westbury, Old Westbury, New York 11568

\author{
R. W. Berg and N. J. Bjerrum
}

Molten Salts Group, Chemistry Department A, The Technical University of Denmark, 2800 Lyngby, Denmark

\section{ABSTRACT}

A new, inorganic low melting electrolyte with the composition $\mathrm{LiAlCl}_{4}-\mathrm{NaAlCl}_{4}-\mathrm{NaAlBr}_{4}-\mathrm{KAlCl}_{4}$ (3:2:3:2) [or equivalently $\left.\mathrm{LiAlBr}_{4}-\mathrm{NaAlCl}_{4}-\mathrm{KAlCl}_{4}(3: 5: 2)\right]$ has been developed. The melting point for this neutral melt is $86^{\circ} \mathrm{C}$; the decomposition potential is approximately $2.0 \mathrm{~V}$; the ionic conductivity is measured in the range $97^{\circ}-401^{\circ} \mathrm{C}$ and is $0.142 \mathrm{~s} \mathrm{~cm}{ }^{-1}$ at $100^{\circ} \mathrm{C}$, and the density is $2.07 \mathrm{~g} \mathrm{~cm}^{-3}$. The conductivity seems to be an almost linear combination of the conductivities of the four individual halo salts which form the melt. Other examined higher melting mixtures exhibit conductivities deviating less than $\pm 10 \%$ from their combination expectations. The low melting electrolyte is employed in the rechargeable battery system $\mathrm{Al} /$ electrolyte $/ \mathrm{Ni}_{3} \mathrm{~S}_{2}$ at $100^{\circ} \mathrm{C}$. The open-circuit voltage of this system is from 0.82 to $1.0 \mathrm{~V}$. Dendrite-free aluminum deposits are obtained. The cycling behavior of the battery system is reported.

The need for better rechargeable batteries is wellknown. Most authors working with molten salt batteries have used alkali metal anodes. In the last few years, aluminum has instead been investigated for battery suitability, especially in Denmark (1-3) and Japan (4). Melts of $\mathrm{NaCl}-\mathrm{AlCl}_{3}$ or $\mathrm{KCl}-\mathrm{NaCl}-\mathrm{AlCl}_{3}$ have been the most popular electrolytes in the temperature range from $130^{\circ}$ to $240^{\circ} \mathrm{C}$, but room-temperature molten salts, such as imidazoliumor butyl-pyridinium-chloride aluminum chloride mixtures, have also been used in a number of cases [see Ref. (5) for a recent survey].

The advantage of electrolytes that can be used at room temperature is obvious, but unfortunately the above-mentioned large-cation organic melts have low ionic conductivities and high equivalent weights compared to the inorganic medium- or high-temperature melts. Further the organic melts are less stable, depending on composition, in contact with aluminum metal.

Therefore, it is desirable to develop an inorganic electrolyte which is molten at room temperature. So far $\mathrm{NaAlCl}_{4}$ has been used at $175^{\circ} \mathrm{C}$ in most of our battery work (1-3). When pure, it melts at $156.7^{\circ} \pm 0.1^{\circ} \mathrm{C} \mathrm{(6).} \mathrm{If} \mathrm{NaCl}$ is mixed with $\mathrm{KCl}$ and sufficient $\mathrm{AlCl}_{3}$ is added, it is possible to reach very low melting acidic compositions; melting points down to $70^{\circ} \mathrm{C}$ have been reported (7). Unfortunately, the ionic conductivity is low and the vapor pressure is fairly high. This, among other things, makes acidic melts (i.e., excess of $\mathrm{AlCl}_{3}$ ) undesirable as battery electrolytes.

We adopted another policy in trying to find a low-temperature electrolyte, mixing alkali tetrahalo-aluminate salts which are neutral. By careful purification of the chemicals followed by mixing various amounts, we have succeeded in obtaining an electrolyte with a rather low melting point, as described elsewhere (8). Here, preliminary determinations of some physicochemical properties are reported.

*Electrochemical Society Active Member.
Finally, to examine the applicability of the melt, five test cells have been constructed, three in a new cell design and two in the usual one. The cells were tested at $100^{\circ} \mathrm{C}$ and compared to earlier (1-2) measurements on a similar cell system with a $\mathrm{NaAlCl}_{4}$ electrolyte at $175^{\circ} \mathrm{C}$.

\section{Experimental}

All manipulations with the chemicals were performed in nitrogen-filled glove boxes.

The alkali halides were made from analytical-grade reagents purified in the molten state by flushing with dry, analytical-grade hydrogen halide gas (6). The aluminum halides were purified by distillation (6).

The individual alkali aluminum halide salts were made from the above-mentioned salts and purified by recrystallization or zone refining, as described recently (9). The electrolyte was finally made by weighing three or four salts in the wanted ratios and sealing the ampul. After equilibration at $125^{\circ} \mathrm{C}$ in a rocking furnace, the electrolyte was quickly solidified. The materials were then ground in a glove box and kept in sealed ampuls until used.

The nickel sulfide electrodes were made from a mixture of $\mathrm{Ni}_{3} \mathrm{~S}_{2}$ (from Cerac, 99.9\%), active carbon powder (Darco G60 from Fluka), and a Teflon dispersion (from du Pont). This mixture was pressed onto a fine nickel grid. As separator, either boron nitride felt obtained from Argonne $\mathrm{Na}-$ tional Laboratory or a glass felt from Dexter (thickness 2 mm) was used.

The conductivity measurements were performed as earlier described (10). Determination of the particular mixture having the lowest possible melting point was done as described elsewhere (8). The density of the low-melting mixture was determined visually using an ampul with markers immersed in a thermostated oil bath.

The quality of electrolytically deposited aluminum was examined in the cell shown in Fig. 1. Of special interest was whether or not dendrites would be formed during 


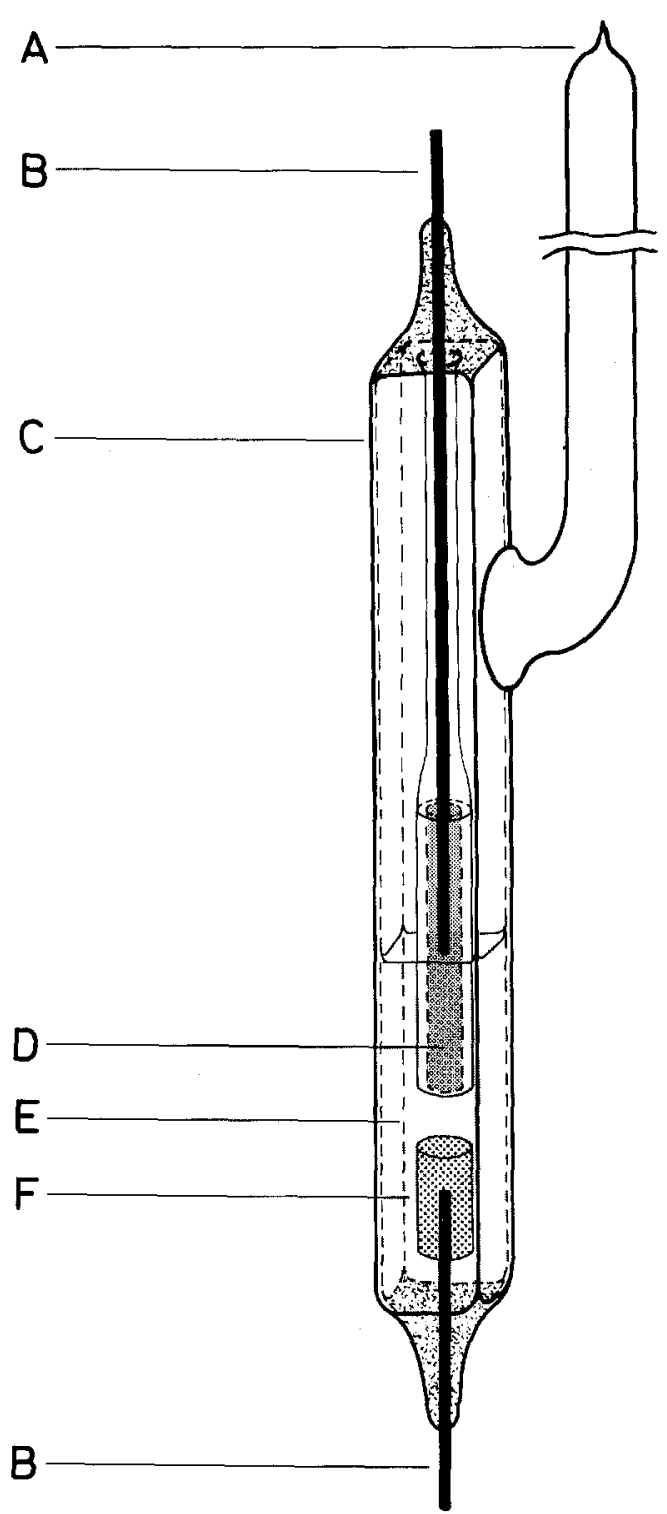

Fig. 1. Electrolysis cell for plateability experiments: A. seal-off, B. tungsten wire, C. square Pyrex glass tubing, D. electrode fused into Pyrex glass, E. electrolyte, and F. Al counter-electrode.

charging (i.e., the plateability). For the cell in Fig. 1, square Pyrex tubing was used to facilitate observations of the electrodes. The cell, filled with electrolyte, was placed such that it could be observed and photographed directly while inside an oven of our own construction, heated with circulated air and controlled by a PID regulator. The electrodes of the cell were observed using a Zeiss Jena Technival 2 stereo microscope equipped with an Olympus OM-2 SLR camera and a Schott KL 1500 cold light source. For cycling of the cell, a high-precision chronoamperostat, built in this laboratory (11), was used, connected to a chart recorder. The same cell and experimental setup was also used to determine the electrochemical window of the electrolyte.

The testing of the cells was performed using an oil bath with mechanical stirring and a PID regulator to control the temperature. The battery test equipment has been described elsewhere (1). The test cell designs are shown in Fig. 2 and 3.

\section{Results and Discussion}

Melting point.-By observing the melting points of a large number of mixtures (8), it was found that the 3:5:2 $\mathrm{LiAlBr}-\mathrm{NaAlCl}_{4}-\mathrm{KAICl}_{4}$ melt was the one which remained totally liquid down to the lowest temperature: $86^{\circ} \pm 1^{\circ} \mathrm{C}$.

Density.-The density $\rho$ of the mixture was measured at ca. $100^{\circ} \mathrm{C}$ to be $2.07 \pm 0.02 \mathrm{~g} \cdot \mathrm{cm}^{-3}$.

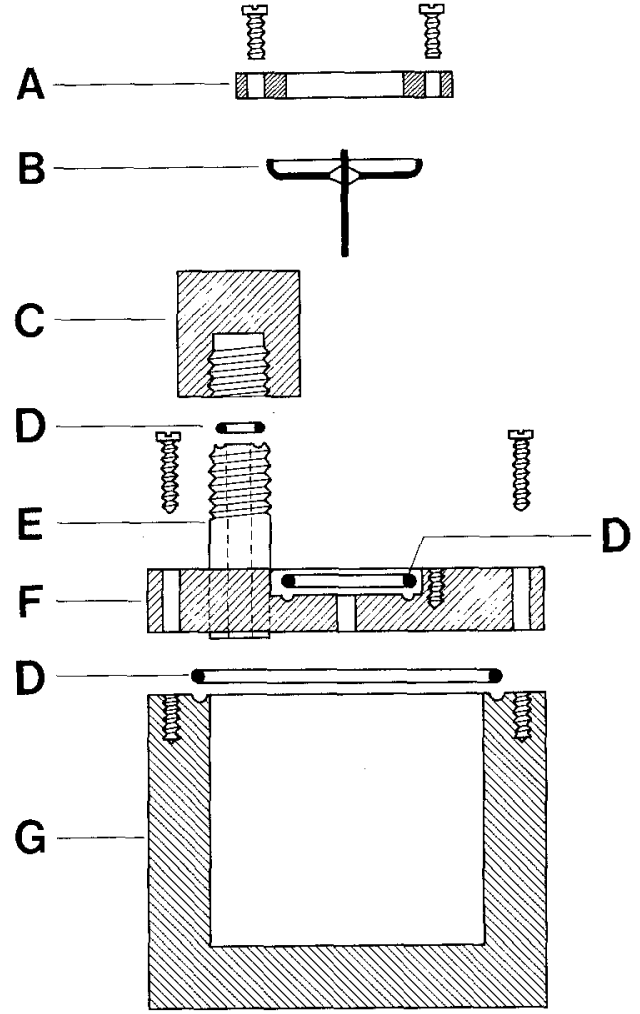

Fig. 2. Vacuum-tight battery housing of test cell: A. aluminum disk to hold kovar disk (B) on its place, B. kovar disk with glass feed-through and stainless-steel wire as positive terminal, $C$. filling tube cap, $D$. O-ring, E. electrolyte filling tube, F. cell lid, and G. aluminum cell house (negative electrode).

Plateability.--In the cell shown in Fig. 1, aluminum was deposited on the carbon electrode (D) by electrolysis. Cathodic current densities from 1.4 to $706 \mathrm{~mA} / \mathrm{cm}^{2}$ were used. The times were chosen so that the total charge passed was ca. $2 \mathrm{C}$ in each case, i.e., $30 \mathrm{C} / \mathrm{cm}^{2}$. This amounts to an aluminum layer of $0.01 \mathrm{~mm}$. The potential was recorded during electrolysis.

After formation, the aluminum deposit was photographed. In all experiments with $1.4-70 \mathrm{~mA} / \mathrm{cm}^{2}$, a dense layer of aluminum was obtained. This corresponds to a high plateability, in contrast to what was found previously for $\mathrm{NaAlCl}_{4}$ melts $(3,12)$. At the highest current densities $140-706 \mathrm{~mA} / \mathrm{cm}^{2}$ the deposits were, however, more porous (i.e., the layer appeared thicker and less dense), but absolutely no dendrites or other well-defined crystals were seen (in contrast to what was seen in $\mathrm{NaAlCl}_{4}$ electrolytes, cf. Fig. 4). No passivation phenomenon was observed.

After each plating, all the aluminum was stripped off again by reversing the potential. The glassy carbon electrode was perfectly smooth (mirror-like) when a new deposition electrolysis was started.

Anodic decomposition potential.-Reverse electrolysis (electrode stripping) was used to determine the "electrochemical window" of the low melting electrolyte. The anodic current was measured as a function of the applied potential. At the same time, the cell was observed for finding the potential at which evolution of a brown gas $\left(\mathrm{Br}_{2}\right)$ began. By plotting the current vs. voltage and extrapolating toward zero current, and comparing the visual observation of bromine evolution, a decomposition value of $2.0 \pm 0.1 \mathrm{~V}$ at $100^{\circ} \mathrm{C}$ was obtained.

This value should be compared to a value of $2.5 \pm 0.1 \mathrm{~V}$, obtained at $175^{\circ} \mathrm{C}$ by extrapolation of similar measurements (13) on a near-neutral $\mathrm{NaCl}-\mathrm{AlCl}_{3}$ molten salt in the temperature range $300^{\circ}-660^{\circ} \mathrm{C}$. Our own determination. of the decomposition potential of molten $\mathrm{NaAlCl}_{4}$ at $175^{\circ} \mathrm{C}$ was $2.4 \pm 0.1 \mathrm{~V}(12)$. In this case, a yellow gas $\left(\mathrm{Cl}_{2}\right)$ evolved (according to the reaction $4 \mathrm{AlCl}_{4}^{-} \rightarrow \mathrm{Cl}_{2}+2 \mathrm{Al}_{2} \mathrm{Cl}_{7}^{-}+2 e^{-}$). The lower decomposition potential of the low-temperature 


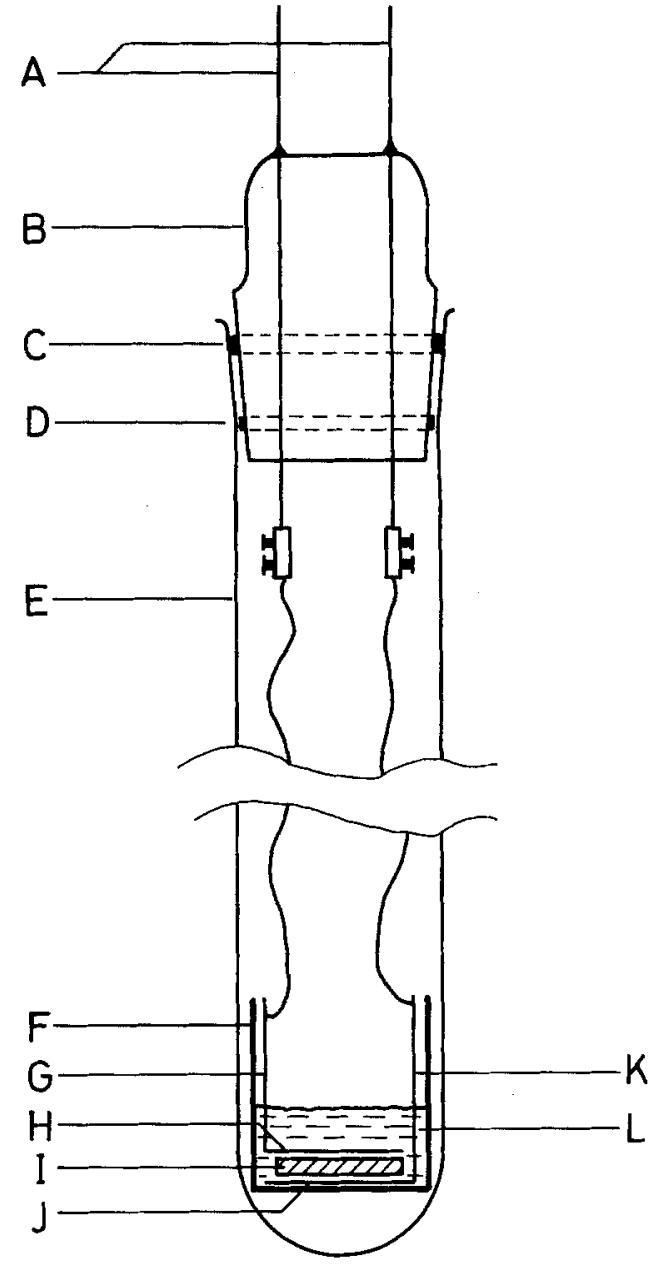

Fig. 3. Aluminum/metal sulfide experimental cell: A. tungsten wire, B. Pyrex glass top (Witeg conical joint), C. Viton O-ring (integrated in the male joint), D. square Teflon gasket (integrated in the male joint), E. Pyrex glass tube, F. Pyrex glass beaker, G. anode terminal (Al), $H$. aluminum anode, I. seperator (glass felt), J. metal sulfide cathode, $K$. nickel mesh cothode terminal, and L. molten salt electrolyte.

electrolyte is due to the lower decomposition potential of the bromide content of the electrolyte.

Conductivity of several mixtures, including the low melting electrolyte.--The chosen compositions and the results of our measurements are presented in Table I and in Fig. 5. The known conductivity $\kappa_{\mathrm{i}}, \mathrm{i}=1,2,3,4$, of the four "parent" tetrahalo compounds $(10,14-17)$ from which the low melting system can be made [i.e., $\mathrm{LiAlCl}_{4}-\mathrm{NaAlCl}_{4}-\mathrm{NaAlBr}_{4^{-}}$ $\left.\mathrm{KAlCl}_{4}(3: 2: 3: 2)\right]$ are also included. It can be seen that the conductivity of the low melting mixture is not far from a weighted average (based on the molar fractions $X_{\mathrm{i}}$ ) of the four individual salts. Roughly, this is also true for the other mixtures.

In the temperature range $267^{\circ}-349^{\circ} \mathrm{C}$ where comparison can be made, quantitative examinations show that the relative difference $\delta$ between the measured conductivity $\kappa_{\text {obs }}$ and the weighted average conductivity $\left(\kappa_{\text {model }}=\kappa_{1} X_{1}+\kappa_{2} X_{2}+\kappa_{3} X_{3}+\kappa_{4} X_{4}\right)$ for the low-melting mixture varies between -0.8 and $-3.0 \%$. This shows that we are not dealing with entirely ideal liquids. For this and for the other examined melts, the maximum relative deviation $\delta_{m}=\left(\kappa_{\mathrm{obs}}-\kappa_{\text {model }}\right) / \kappa_{\text {model }}$ is indicated in Table I.

The conductivity of a mixed melt naturally decreases with decreasing temperature. Yet, even at the melting point of the low melting mixture, a fairly high conductivity is found (extrapolated value of $\kappa_{o b s}=0.117 \mathrm{~s} \mathrm{~cm}^{-1}$ at $86^{\circ} \mathrm{C}$ ).

Using the measured conductivity data (Table I), we have fitted the conductivity for each mixture, $\kappa$, to a polynomium as a function of temperature ( $T$ in $\mathrm{K}$; temperature range ca. $373-673 \mathrm{~K})$.

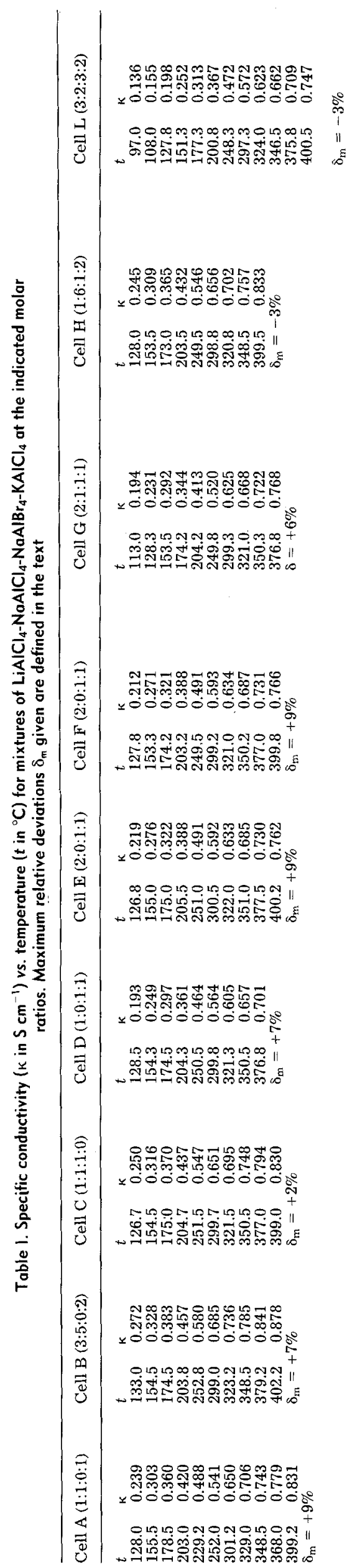

Downloaded 09 Oct 2009 to 192.38.67.112. Redistribution subject to ECS license or copyright; see http://www.ecsdl.org/terms use.jsp 

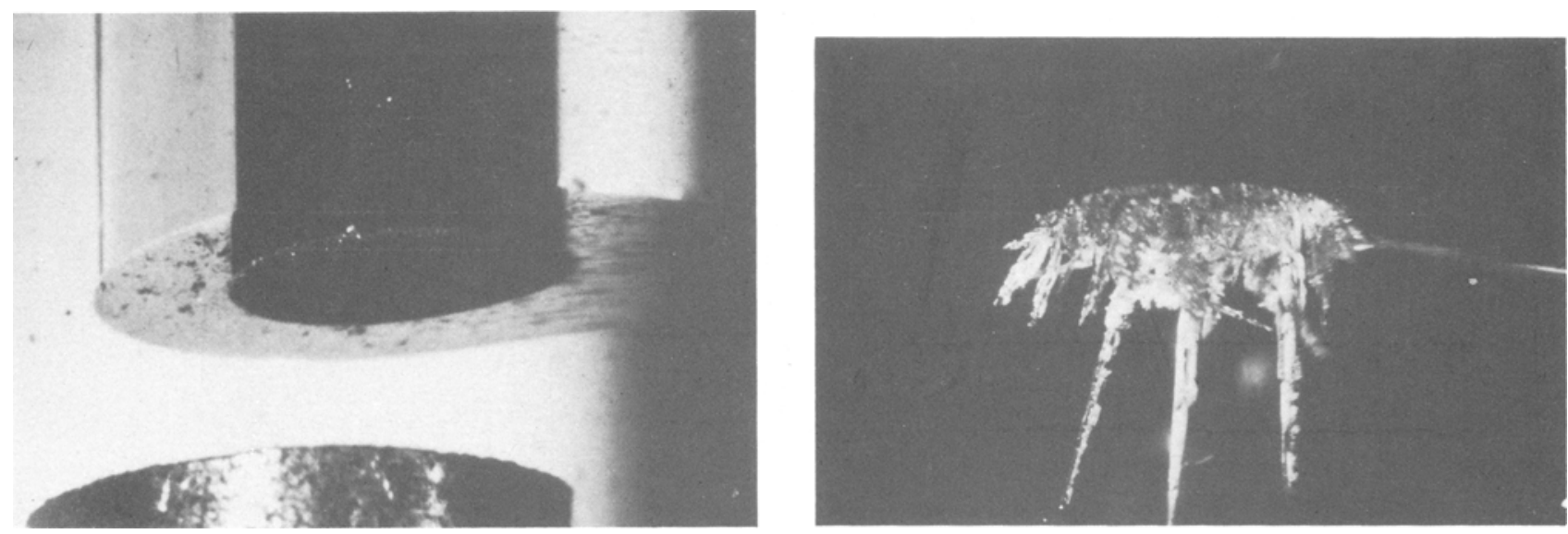

Fig. 4. Photographs showing typical deposits obtained during plateability experiments, using (a, left) the new low-temperature melt at $100^{\circ} \mathrm{C}$ and (b, right) the $\mathrm{NaAlCl}_{4}$ electrolyte at $175^{\circ} \mathrm{C}$, in both cases using a current density of $1.4 \mathrm{~mA} / \mathrm{cm}^{2}$. In (a), a rather dense $\mathrm{Al}$ plate and in (b) $\mathrm{Al}$ dendrites are formed.

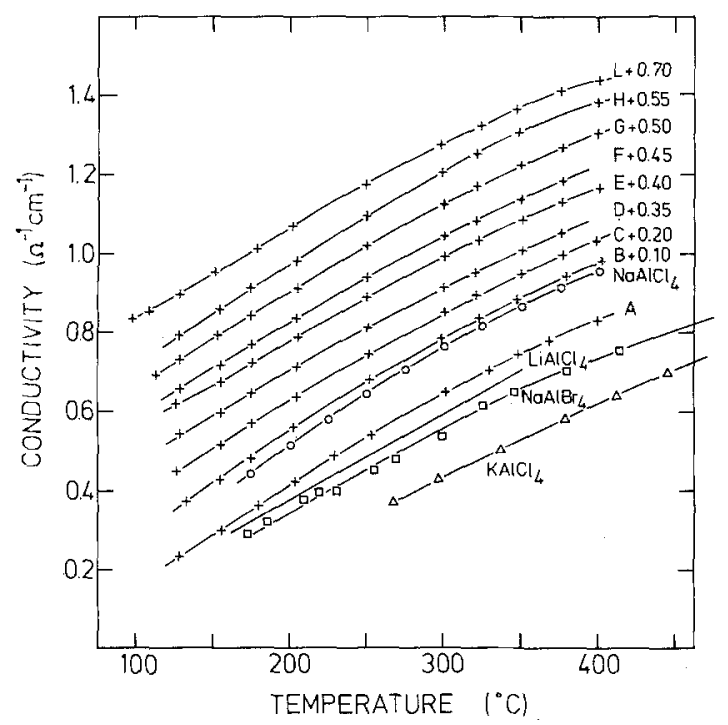

Fig. 5. Specific conductivity vs. temperature of $\mathrm{LiAlCl}_{4}(14), \mathrm{NaAlCl}_{4}$ (10), $\mathrm{NaAlBr}_{4}(15), \mathrm{KAICl}_{4}(16)$, and mixtures thereof (our experiments A-L). For clarity some data are offset in specific conductivity by the amounts specified.

$$
\mathrm{\kappa}=A+B \cdot 10^{-3}(T-448.2)-C \cdot 10^{-6}(\mathrm{~T}-448.2)^{2}
$$

The calculated coefficients $A, B$, and $C$ for the different compositions and the perfection of fit are shown in Table II.

Test of batteries.-A number of different test cell designs have been employed in our earlier battery work (1). For the low-temperature electrolyte, a new type of cell was used as shown in Fig. 2. Cells A, B, and C had this design but differed by the shape of the cathode: a flat circular-, a cylinder wall-, and a thick cylinder wall-cathode, respectively. The open-circuit voltage at $100^{\circ} \mathrm{C}$ was, after assembly, $0.87,1.0$, and $0.83 \mathrm{~V}$, respectively. This variation is fairly large. However, the phenomenon is well known from other types of cells (e.g., standard $\mathrm{Zn} / \mathrm{MnO}_{2}$ cells where the variation typical is $20-50 \mathrm{mV}$ ). The variation could be due to a lack of a well-defined redox couple until the cell is discharged or small variations in the composition of the used materials. The three cells were tested at $100^{\circ} \mathrm{C}$. A representative number of cycles are shown in Fig. 6. Assuming that the cathodic discharge reaction is

$$
4 \mathrm{e}^{-}+\mathrm{Ni}_{3} \mathrm{~S}_{2} \rightarrow 3 \mathrm{Ni}+2 \mathrm{~S}^{2-}
$$

the theoretical capacities were $0.204,1.133$, and $7.586 \mathrm{Ah}$ for cells $\mathrm{A}, \mathrm{B}$, and $\mathrm{C}$, respectively. The total cell reaction is $2 \mathrm{Al}+3 \mathrm{Ni}_{3} \mathrm{~S}_{2} \rightarrow 9 \mathrm{Ni}+2 \mathrm{Al}^{3+}+6 \mathrm{~S}^{2-} ;$ however, all cells were cathode limited.

The charge and discharge conditions for cells $A$ and $B$ were $5 \mathrm{~mA}$ and $5 \mathrm{~h}$, respectively. For cell $\mathrm{C}$ the conditions were $5 \mathrm{~mA}$ and $5 \mathrm{~h}$ until cycle $39,10 \mathrm{~mA}$ and $5 \mathrm{~h}$ until cycle $68,15 \mathrm{~mA}$ and $5 \mathrm{~h}$ until cycle $89,20 \mathrm{~mA}$ and $5 \mathrm{~h}$ until cycle $108,25 \mathrm{~mA}$ and $5 \mathrm{~h}$ until cycle 128 , and $50 \mathrm{~mA}$ and $5 \mathrm{~h}$ until testing was terminated.

A graphical presentation which helps in the evaluation of the results is shown in Fig. 7. The charge efficiency is defined as (discharge)/(charge) and the energy efficiency is defined as charge efficiency times (average discharge voltage)/(average charge voltage). The cell performance for cells $\mathrm{A}, \mathrm{B}$, and $\mathrm{C}$ seems not good compared to the $\mathrm{Al} / \mathrm{NaCl}$ $\mathrm{AlCl}_{3} / \mathrm{Ni}_{3} \mathrm{~S}_{2}$ system at $175^{\circ} \mathrm{C}(1-2)$. The lower temperature may be causing some of the difference. The metal housing excludes visual observation of the interior of the cell. The

Table II. Coefficients for empirical polynomials

$$
\kappa=A+B \cdot 10^{-3} \cdot(T-448.2)-C \cdot 10^{-6} \cdot(T-448.2)^{2}
$$

\begin{tabular}{|c|c|c|c|c|c|}
\hline Cell & $\begin{array}{l}\mathrm{A} \text { (constant) } \\
\mathrm{S} \mathrm{cm}^{-1}\end{array}$ & $\stackrel{\mathrm{B}}{\mathrm{S} \mathrm{cm}} \mathrm{cm}^{-1} \mathrm{~K}^{-1}$ & $\mathrm{~S} \mathrm{~cm}^{-1} \mathrm{~K}^{-2}$ & $\begin{array}{l}\text { Error } \\
\mathrm{S} \mathrm{cm}^{-1}\end{array}$ & $\mathrm{R}^{2 \mathrm{~d}}$ \\
\hline A & $0.3555(16)^{\mathrm{b}}$ & $2.533(35)$ & $1.77(18)$ & 0.004 & 0.9997 \\
\hline B & $0.3854(10)$ & $2.676(23)$ & $2.18(12)$ & 0.002 & 0.9999 \\
\hline $\mathrm{C}$ & $0.3695(12)$ & $2.463(25)$ & $1.78(13)$ & 0.003 & 0.9999 \\
\hline $\mathrm{D}$ & $0.2988(12)$ & $2.280(27)$ & $1.37(16)$ & 0.003 & 0.9999 \\
\hline $\mathbf{E}$ & $0.3254(20)$ & $2.279(43)$ & $1.42(23)$ & 0.005 & 0.9996 \\
\hline $\mathbf{F}$ & $0.3246(9)$ & $2.368(19)$ & $1.76(10)$ & 0.002 & 0.9999 \\
\hline $\mathrm{G}$ & $0.3469(10)$ & $2.413(18)$ & $1.56(13)$ & 0.002 & 0.9999 \\
\hline $\mathrm{H}$ & $0.3677(23)$ & $2.590(50)$ & $2.20(27)$ & 0.005 & 0.9995 \\
\hline $\mathrm{L}$ & $0.3120(19)$ & $2.258(28)$ & $1.36(18)$ & 0.005 & 0.9996 \\
\hline
\end{tabular}

for the specific conductivity of molten $\mathrm{MAIX}_{4}$ mixtures ${ }^{a}$

Temperature range ca. $373-673 \mathrm{~K}$.

${ }^{\text {b.e. }}, 0.3555 \pm 0.0016$.

${ }^{\mathrm{c}}$ Root mean square error of model fit to the data.

${ }^{\mathrm{d}}$ Coefficient of determination. 

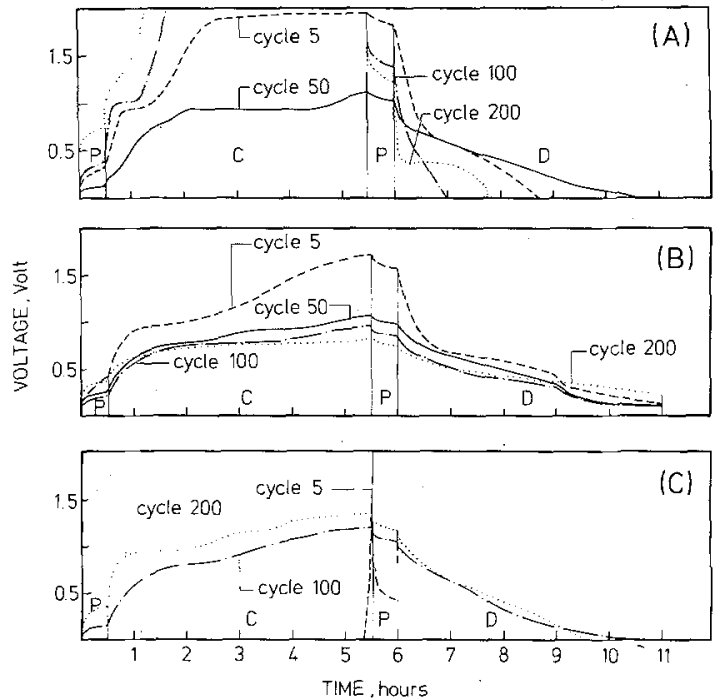

Fig. 6. Charge/discharge curves for three aluminum housing experimental cells (design shown in Fig. 1). (A) Theoretical cathode capacity $204 \mathrm{mAh}$, charge-discharge conditions $5 \mathrm{~mA}$ and $5 \mathrm{~h}$. (B) Theoretical cathode capacity $1133 \mathrm{mAh}$, charge/discharge conditions $5 \mathrm{~mA}$ and $5 \mathrm{~h}$. (C) Theoretical cathode capacity $7586 \mathrm{mAh}$, charge/discharge conditions $5 \mathrm{~mA}$ and $5 \mathrm{~h}$ until cycle $39,10 \mathrm{~mA}$ and $5 \mathrm{~h}$ until cycle $68,15 \mathrm{~mA}$ and $5 \mathrm{~h}$ until cycle $89,20 \mathrm{~mA}$ and $5 \mathrm{~h}$ until cycle 108, $25 \mathrm{~mA}$ and $5 \mathrm{~h}$ until cycle 128 , and $50 \mathrm{~mA}$ and $5 \mathrm{~h}$ until test was terminated. C, D, and $P$ indicate charge, discharge, and pause, respectively. For details see text.

highly fluctuating efficiencies are probably related to shorting problems. Inspection of cell A (after termination of the experiment) showed that the glass-pellet feedthrough was not corroded. Therefore, it is not likely that the problem is located there but rather is caused by a shorting between the stainless-steel wire and the cell lid (in Fig. 2, between $B$ and F). However, the fact that the cells can exhibit high current efficiencies can be interpreted to show that the battery system is promising.

In order to test the idea that the weak overall performance of the low-temperature cell system was due to difficulties in the new cell design, two more cells (D and $E$ ) in our usual glass cell design (see Fig. 3) were made and cy-
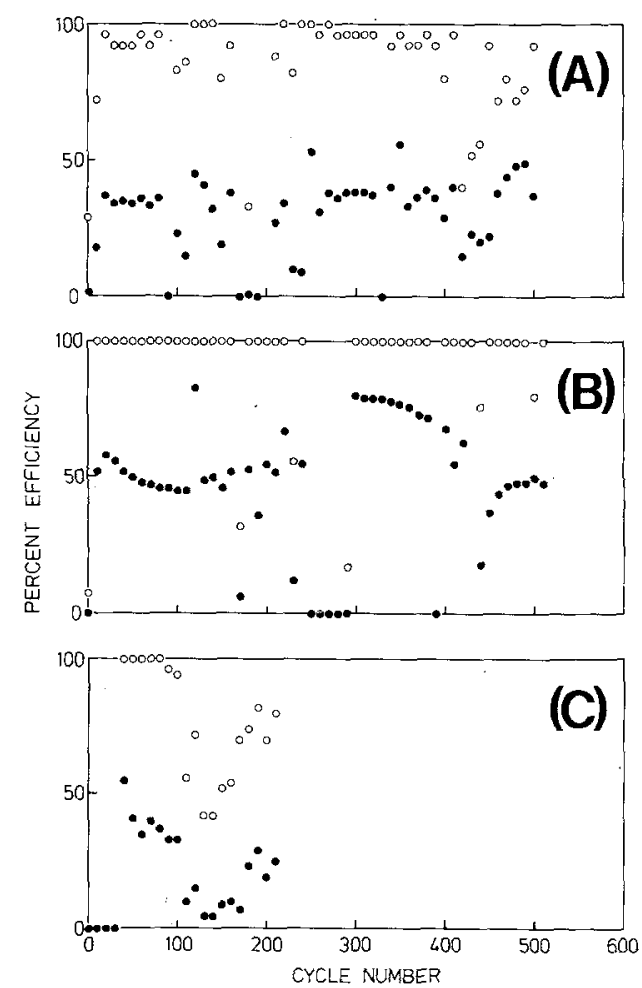

Fig. 7. Experimental batteries A, B, and C. Results calculated for every tenth cycle. Charge efficiency $O$, energy efficiency -

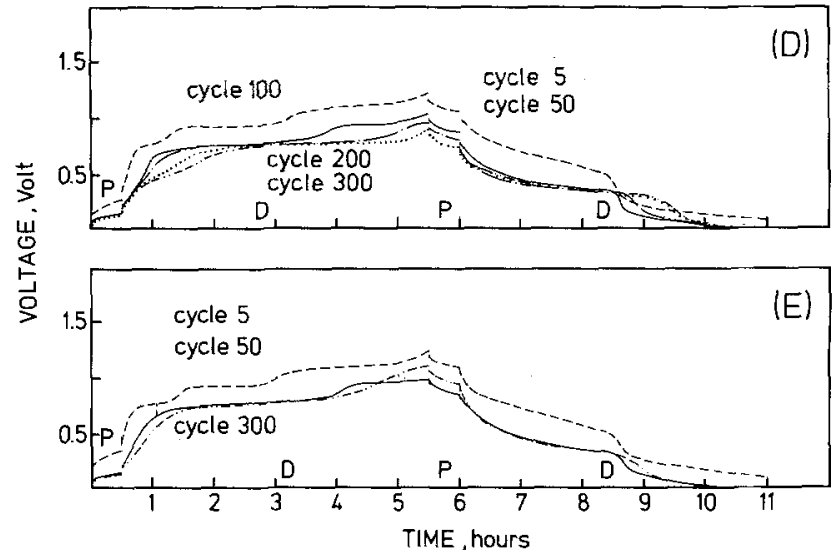

Fig. 8. Charge/discharge curves for two glass housing experimental cells $D$ and $E$ (design shown in Fig. 2). Theoretical capacities 0.290 and $0.285 \mathrm{Ah}$, respectively. Test conditions $5 \mathrm{~h}$ and $5 \mathrm{~mA}$ for both cells.

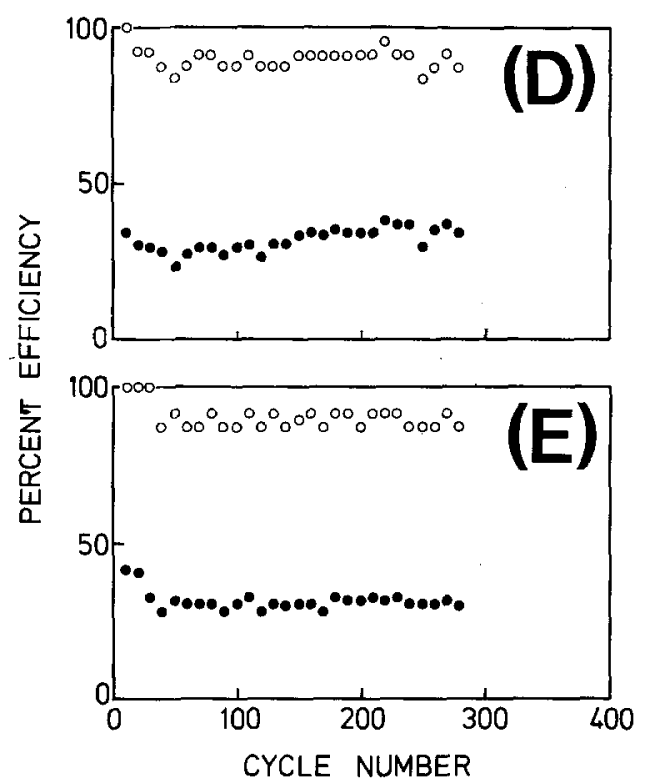

Fig. 9. Experimental batteries $D$ and E. Results calculated for every tenth cycle. Charge efficiency $O$, energy efficiency

cled with the same kind of electrodes and electrolytes as for cells A-C. The open-circuit voltages were 0.824 and $0.891 \mathrm{~V}$, while the theoretical discharge capacities were 0.290 and $0.285 \mathrm{Ah}$, respectively. These cells were also cathode limited. The charge/discharge conditions were $5 \mathrm{~h}$ and $5 \mathrm{~mA}$. The cycling results are shown in Fig. 8. Charge and energy efficiencies are shown in Fig. 9. As can be seen from these figures, the consistency of the results are far better for these cells than for cells A-C, which had metal aluminum housing.

The cell voltages under load were quite low and the energy efficiencies small compared to similar $\mathrm{Al} / \mathrm{Ni}_{3} \mathrm{~S}_{2}$ cells with $\mathrm{NaAlCl}_{4}$ electrolyte at $175^{\circ} \mathrm{C}$.

Research on the cell reaction mechanisms, perhaps clarifying some of these problems, is in progress (12).

\section{Acknowledgments}

We would like to thank J. E. Battles, Argonne National Laboratory, USA, for a sample of boron nitride felt, and GN Batteries A/S (former Hellesens Batteries A/S) for a sample of Tefion dispersion. We would like to thank the Danish Ministry of Energy, the Danish Technical Science Research Foundation, and Director Ib Henriksens Foundation for financial support. Also, T. L. Lauridsen is thanked for measuring the conductivities.

Manuscript submitted May 9, 1988; revised manuscript received Sept. 6, 1988. This was Paper 1547 presented at the Honolulu, HI, Meeting of the Society, Oct. 18-23, 1987. 


\section{REFERENCES}

1. H. A. Hjuler, R. W. Berg, and N. J. Bjerrum, Proc. 14th Intl. Power Sources Symp. 1984, Brighton, England, 10, pp. 1-21 (1985).

2. H. A. Hjuler, R. W. Berg, and N. J. Bjerrum, Proc. 31st Power Sources Symp., pp. 60-73 (1984).

3. Q. Li, H. A. Hjuler, R. W. Berg, and N. J. Bjerrum, Submitted to This Journal.

4. N. Takami and N. Koura, Denki Kagaku, 54, 498 (1986), and references cited therein.

5. J. S. Wilkes, "A Bibliography of Room Temperature Chloroaluminate Molten Salts," FJSRL-TM-84-0006, 1984, available from the F. J. Seiler Research Laboratory, USAFA, Colorado Springs, Colorado 808406528 .

6. R. W. Berg, H. A. Hjuler, and N. J. Bjerrum, Inorg. Chem., 23, 557 (1984).

7. W. Fischer and A. L. Simon, Z. Anorg. Allg. Chem., 306,
1 (1960).

8. R. W. Berg, Work in progress.

9. R. W. Berg and T. Østvold, Acta Chem. Scand, A40, 445 (1986).

10. H. A. Hjuler, R. W. Berg, K. Zachariassen, and N. J. Bjerrum, J. Chem. Eng. Data, 30, 203 (1985).

11. R. Fehrmann, N. J. Bjerrum, and F. W. Poulsen, Inorg. Chem., 17, 1195 (1978).

12. H. A. Hjuler, R. W. Berg, and N. J. Bjerrum, Unpublished results.

13. M. G. Kher and P. S. Mene, Indian J. Chem., 1, 185 (1963).

14. R. A. Carpio, L. A. King, F. C. Kibler, and A. A. Fannin Jr., This Journal, 126, 1650 (1979).

15. C. R. Boston, ibid., 118, 425 (1971).

16. C. R. Boston, L. F. Grantham, and S. J, Yosim, ibid., 117, $28(1970)$

17. V. A. Petrov, A. G. Morachevskii, and L. D. Petrova, Zh. Prikl. Khim., 59, 667 (1986).

\title{
The Electrochemical Behavior of Lithium Salt Solutions of $\gamma$-Butyrolactone with Noble Metal Electrodes
}

\author{
Doron Aurbach* \\ Department of Chemistry, Bar-Ilan University, Ramat-Gan 52100, Israel
}

\begin{abstract}
The electrochemical behavior of lithium salt solutions of $\gamma$-butyrolactone with noble metal electrodes (Ag, $\mathrm{Au}, \mathrm{Pt}$ ) was rigorously investigated. Linear sweep voltammetry in conjunction with ex situ FTIR (external reflectance mode) were used in order to analyze various electrode processes in these systems. It was found that the solvent, traces of water and oxygen, is reduced at a potential higher than the potential of lithium bulk deposition (which is the cathodic limiting reaction). These processes for..n several types of surface films that control the electrochemical behavior of these systems and lead to their apparent stability within an electrochemical window of more than $4 \mathrm{~V}$. BL reduction processes precipitate derivatives of lithium butyrate on the electrode surfaces. Water and oxygen reductions form films of $\mathrm{LiOH}^{\mathrm{ind}} \mathrm{LiO}$, respectively. These compounds react further, nucleophilically with the solvent to form secondary films. The structure of these films has a pronounced effect on the lithium deposition and dissolution processes. Hence, these systems should also be categorized as solid electrolyte interphase (SEI) systems.
\end{abstract}

Polar aprotic solvents such as ethers, alkyl carbonates, acetonitrile, dimethyl sulfoxide, and others become more and more important in modern electrochemistry $(1,2)$.

In recent years, great attention has been paid to the study of the electrochemical behavior of active metals, especially lithium, in polar aprotic systems due to the importance of this subject to the area of high energy density batteries (3). It was found that the apparent stability of lithium in solvents such as propylene carbonate (4) or ethers (5) should be attributed to the formation of protecting films that cover the active metal surface and block it from further corrosion (6-9).

The interface of lithium in these systems is described in terms of solid electrolyte interphase (S.E.I.) $(10,11)$ rather than as simple metal solution interface.

In contrast to the efforts that were invested in the study of the electrochemical behavior of polar aprotic systems with active metal electrodes, not much has been done to date in the study of the electrochemical behavior of these solvents with noble metal electrodes (e.g., gold and platinum). One of the solvents of interest for lithium batteries and other uses in nonaqueous electrochemistry is $\gamma$-butyrolactone (BL) (12-13). In a recent work we rigorously studied the lithium-BL system and analyzed the structure of surface films formed on the active metal in pure and contaminated BL solutions (16).

The present work has involved an investigation of the electrochemical behavior of pure and contaminated lithium salt solutions of BL with noble metal electrodes (gold, platinum, and silver). The various electrochemical processes relevant to these systems were investigated using linear sweep voltammetry. Surface-sensitive FTIR spec-

* Electrochemical Society Active Member. troscopy was applied in order to characterize the electrode surfaces after being treated electrochemically in solutions.

In contrast to the lithium surface where several processes occur simultaneously, we expected to be able to study separately the various reduction processes relevant to the BL system and to explore how they influence each other by using noble metal electrodes.

\section{Experimental}

The electrochemical measurements and all the preparations for the spectral studies were carried out at room temperature under a high-purity argon atmosphere in VAC glove boxes. The experimental conditions as well as solvent and $\mathrm{LiClO}_{4}$ purification and the preparation of contaminated solutions are described elsewhere (16-18). $\mathrm{Li}_{2} \mathrm{O}_{2}$, $\mathrm{Li}_{2} \mathrm{O}$ (Aldrich), $\mathrm{KO}_{2}$ (Callery, USA), LiAsF ${ }_{4}$ (USS Agrichemical), and $\mathrm{Ag}, \mathrm{Au}$, and $\mathrm{Pt}$ wires and foils (Holland Israel) were used.

The electrochemical treatments and measurements were carried out with the equipment of PAR [Ref. (16-18)]. FTIR spectra were obtained with Nicolet $60 \mathrm{SXB}$ spectrometer equipped with a ditriglycine sulfate (DTGS) detector, a Spectratech FT-80 grazing angle reflection attachment, and a $\mathrm{ZnSe}$ polarizer.

The voltammetric behavior of the BL solutions with noble metal electrodes was studied with a three-electrode cell described in Fig. 1.

For the spectroscopic measurements, silver and platinum plates $0.5 \mathrm{~mm}$ thick $(4 \times 2 \mathrm{~cm})$ were polished with $0.3 \mu \gamma$ alumina and glass plates $1 \mathrm{~mm}$ thick $(4 \times 2 \mathrm{~cm})$ were covered with $2000 \AA$ thick gold layer (using sputtering technique). These mirror-like reflective plates were used as working electrodes in a three-electrode cell in which a lithium plate and a lithium strip were the counter and the 